\title{
Density functional theory investigation of the enhanced adsorption mechanism and potential catalytic activity for formaldehyde degradation on $\mathrm{Al}$-decorated $\mathrm{C}_{2} \mathrm{~N}$ monolayer
}

\author{
Yuetan Su, Wenlang Li, Guiying Li, Zhimin Ao *, Taicheng An \\ Guangzhou Key Laboratory of Environmental Catalysis and Pollution Control, School of Environmental Science and Engineering, Institute of Environ- \\ mental Health and Pollution Control, Guangdong University of Technology, Guangzhou 510006, Guangdong, China
}

\section{A R T I C L E I N F O}

\section{Article history:}

Received 21 October 2018

Accepted 17 November 2018

Published 5 May 2019

\section{Keywords:}

$\mathrm{C}_{2} \mathrm{~N}$

Density functional theory

Two-dimensional material

Formaldehyde

Adsorption

Catalytic degradation

\begin{abstract}
A B S T R A C T
Carbonyl compounds, in particular formaldehyde ( $\mathrm{HCHO}$ ), are among the most common indoor air pollutants that have been found to be toxic to humans. Thus, in this study, density functional theory (DFT) calculations are performed to study the adsorption properties of HCHO on pristine and Al-decorated $\mathrm{C}_{2} \mathrm{~N}$ monolayer. The results indicate that Al-decorated $\mathrm{C}_{2} \mathrm{~N}$ has a strong adsorption ability for $\mathrm{HCHO}$ molecules with an adsorption energy of $-2.585 \mathrm{eV}$. Moreover, partial density of states (PDOS), Mulliken atomic charges, and electron density distributions are calculated to investigate the adsorption enhancement mechanism. The results show that the $\mathrm{Al}$ atom serves as a bridge to connect the adsorbed molecules and the $\mathrm{C}_{2} \mathrm{~N}$ monolayer, thus strengthening the adsorption. Furthermore, we study the adsorption of $\mathrm{H}_{2} \mathrm{O}$ and $\mathrm{O}_{2}$ with the possible generation of hydroxyl $(\bullet \mathrm{OH})$ and superoxide $\left(\mathrm{O}_{2}{ }^{-}\right)$radicals, which are active for $\mathrm{HCHO}$ degradation; the results show that both molecules can also be strongly adsorbed on the Al-decorated $\mathrm{C}_{2} \mathrm{~N}$ surface. In particular, the dissociation of $\mathrm{H}_{2} \mathrm{O}$ provides an excellent precondition for the generation of hydroxyl radicals. Our findings suggest that Al-decorated $\mathrm{C}_{2} \mathrm{~N}$ can be a promising material for the adsorption and subsequent catalytic degradation of $\mathrm{HCHO}$ molecules.
\end{abstract}

(C) 2019, Dalian Institute of Chemical Physics, Chinese Academy of Sciences. Published by Elsevier B.V. All rights reserved.

\section{Introduction}

Energy shortage and environmental pollution are two major global challenges faced by humanity today. Air pollution, which is closely related to human health, has attracted considerable attention in the past few years. Indoor air quality is particularly important for human health because humans spend 70\%-90\% of their life indoors [1]. Carbonyl compounds, in particular formaldehyde (HCHO), are among the most common indoor air pollutants, mainly released from decorating materials, plywood, fiberboard, particleboard, and other artificial boards [2-5]. Long-term exposure to high concentrations of HCHO may cause irritation, allergies, decreased immune function [6], and even nasopharyngeal carcinoma or leukemia $[7,8]$. Therefore, the removal of $\mathrm{HCHO}$ is a necessary measure to reduce air pollution and protect human health.

Various techniques have been reported for dealing with indoor HCHO, and the most common ones are adsorption and

\footnotetext{
* Corresponding author. E-mail: zhimin.ao@gdut.edu.cn

This work was supported by the National Natural Science Foundation of China (21607029, 21777033 and 41373102), the Science and Technology Program of Guangdong Province (2017B020216003), the Science and Technology Program of Guangzhou City (201707010359), the Innovation Team Project of Guangdong Provincial Department of Education (2017KCXTD012), the "1000 Plan" for Young Professionals' Program of China, and the National Supercomputing Centre in Guangzhou. DOI: 10.1016/S1872-2067(18)63201-2 | http://www.sciencedirect.com/science/journal/18722067 | Chin. J. Catal., Vol. 40, No. 5, May 2019
} 
catalytic oxidation. The conventional adsorption methods usually employ porous adsorbents such as activated carbon $[9,10]$, zeolites [9,11], and molecular sieves [12], which have been widely used due to their advantages including simplicity, low cost, and room-temperature operation. However, the limited adsorption capacity and adsorbent regeneration make these systems inadequate to meet present demands [13-16]. Catalytic degradation is another widely studied process to perform HCHO oxidation [17-22]. However, it also has some shortcomings in practical applications. For example, $\mathrm{TiO}_{2}$-based catalysts have been widely investigated, but the relatively wide band gap of $\mathrm{TiO}_{2}$ restricts its light energy utilization; therefore, the degradation efficiency requirements are often unsatisfied [23-25]. Therefore, new catalysts for the effective removal of HCHO are still urgently needed.

Recently, a new type of carbon nitrides, the holey $\mathrm{C}_{2} \mathrm{~N}$ with two-dimensional (2D) structure, has been synthesized through a simple wet-chemical reaction [26]. As a new type of graphene-like porous structure with well-distributed pores, this material has attracted significant attention because of its ultra-large surface area and appropriate band gap value. For example, Zhu et al. [27] prepared $\mathrm{C}_{2} \mathrm{~N}$ for the adsorption of $\mathrm{He}$ atoms. Liu et al. [28] reported that Ca-embedded $\mathrm{C}_{2} \mathrm{~N}$ is an efficient adsorbent for $\mathrm{CO}_{2}$ capture, while Qin et al. [29] employed charge and electric field effects to control $\mathrm{CO}_{2}$ capture and gas separation on a $\mathrm{C}_{2} \mathrm{~N}$ monolayer. Furthermore, in the context of targeting gas pollution, Bhattachayya et al. [30] showed that a $\mathrm{C}_{2} \mathrm{~N}$ monolayer can efficiently trap $\mathrm{HF}, \mathrm{HCN}$, and $\mathrm{H}_{2} \mathrm{~S}$ pollutants, causing different changes in the $I-V$ characteristics of the monolayer, which is a promising feature for the detection of the corresponding gases. These studies show that $\mathrm{C}_{2} \mathrm{~N}$ may be a promising candidate for the adsorption and degradation of HCHO molecules. However, pristine 2D materials cannot always satisfy the demands of practical applications, and functionalization is required in some cases. Previous studies have shown that modification with $\mathrm{Al}$ atoms can in some cases lead to enhanced adsorption capacity. For example, our previous studies have shown that $\mathrm{Al}$ doping of graphene can significant enhance the adsorption of $\mathrm{CO}$ [31] and $\mathrm{H}_{2}$ [32,33]. In addition, Al-modified $\mathrm{MoS}_{2}$ exhibits strong adsorption capacity toward $\mathrm{NO}_{2}$ and $\mathrm{NH}_{3}$ [34], while the enhanced adsorption of HCHO [35], $\mathrm{H}_{2}$ [36], and $\mathrm{CO}_{2}$ [37] has been observed on Al-modified $\mathrm{BN}$ systems. Hence, modification with $\mathrm{Al}$ atoms can be considered as a promising approach for improving the adsorption ability of 2D materials.

Herein, the HCHO adsorption on both pristine and Al-decorated $\mathrm{C}_{2} \mathrm{~N}$ monolayer is modeled using the density functional theory (DFT) method. Moreover, the adsorption capacity toward $\mathrm{H}_{2} \mathrm{O}$ and $\mathrm{O}_{2}$, which are sources of active hydroxyl and superoxide radicals, is investigated for the subsequent catalytic degradation of HCHO. Furthermore, the adsorption enhancement mechanism is analyzed by calculating the partial density of states (PDOS), Mulliken atomic charges, and electron density distribution.

\section{Calculation methods}

All calculations reported in this study were carried out using the DFT-based $\mathrm{DMol}^{3}[38,39]$ module of the Materials Studio software, which includes unique methodologies and an highly efficient optimization for dealing with electrostatic problems. The Perdew-Burke-Ernzerhof (PBE) exchange-correlation functional within the generalized gradient approximation (GGA) was employed in the calculations [40]. It is essential to take into account van der Waals forces to describe the decorated metal atoms and the adsorption of gas molecules; hence, the Tkatchenko-Scheffler (TS) method for the DFT-D correction was used for this purpose. In order to take relativity effects into account, all electrons were included in the calculations, to obtain more accurate results without any special treatment of core electrons. Double numerical plus polarization (DNP) functions were adopted as the basis set. A $24 \AA$ vacuum gap was included above the monolayer to minimize interlayer interactions. A $7 \times 7 \times 1$ Monkhorst-Pack grid of k-points was used, and all atoms were allowed to relax until the residual forces on individual atoms were smaller than $10^{-5} \mathrm{Ha}(1 \mathrm{Ha}=27.211 \mathrm{eV})$. The maximum force and displacement were set to $0.002 \mathrm{Ha} / \AA$ and $0.005 \AA$, respectively.

For examining the structural stability of $\mathrm{Al}$ atoms decorated on the $\mathrm{C}_{2} \mathrm{~N}$ monolayer, the binding energy $E_{\mathrm{b}-\mathrm{Al}}$ was determined by the relation:

$$
E_{\mathrm{b}-\mathrm{Al}}=E_{\mathrm{Al}+\mathrm{C} 2 \mathrm{~N}}-E_{\mathrm{Al}}-E_{\mathrm{C} 2 \mathrm{~N}}
$$

where $E_{\mathrm{Al}+\mathrm{C} 2 \mathrm{~N}}, E_{\mathrm{Al}}$, and $E_{\mathrm{C} 2 \mathrm{~N}}$ represent the total energies of the Al-decorated $\mathrm{C}_{2} \mathrm{~N}$, an independent $\mathrm{Al}$ atom in the slab, and the pristine $\mathrm{C}_{2} \mathrm{~N}$ monolayer, respectively. Moreover, to probe the adsorption of gas molecules on the pristine/Al-decorated $\mathrm{C}_{2} \mathrm{~N}$ systems, the adsorption energy $E_{\text {ad-gas }}$ was determined as:

$$
E_{\text {ad-gas }}=E_{\mathrm{C} 2 \mathrm{~N}+\text { gas }}-E_{\mathrm{C} 2 \mathrm{~N}}-E_{\text {gas }}
$$

where $E_{\mathrm{C} 2 \mathrm{~N}+\text { gas }}, E_{\mathrm{C} 2 \mathrm{~N}}$, and $E_{\text {gas }}$ are the total energies of a gas molecule adsorbed on the $\mathrm{C}_{2} \mathrm{~N}$ layer with or without $\mathrm{Al}$ atoms, the isolated $\mathrm{C}_{2} \mathrm{~N}$ monolayer, and the corresponding isolated gas molecule in the slab, respectively.

\section{Results and discussion}

\subsection{Geometrical structure of pristine and Al-decorated $\mathrm{C}_{2} \mathrm{~N}$}

The optimized structure of the $\mathrm{C}_{2} \mathrm{~N}$ monolayer unit cell is shown in Fig. 1(a), and consists of $12 \mathrm{C}$ and $6 \mathrm{~N}$ atoms (solid black line), with four unit cells forming a uniform hole. The lattice parameters calculated in this study are $a=b=8.325 \AA$, which are consistent with recently reported results $(a=b=$ $8.33 \AA$ A) [41,42]. Moreover, the C-N, C-C(1), and C-C(2) bond lengths are $1.337,1.428$, and $1.470 \AA$, respectively, also in good agreement with the recent theoretical values of $1.337,1.429$, and $1.470 \AA$ [42]. Then, we examined the electronic properties of the pristine $\mathrm{C}_{2} \mathrm{~N}$ monolayer, whose calculated band structure is shown in Fig. 1(b). The figure shows that $\mathrm{C}_{2} \mathrm{~N}$ is a semiconductor with a direct band gap of $1.67 \mathrm{eV}$, in good agreement with the reported theoretical [43] and experimental data (1.66 and $1.96 \mathrm{eV}$, respectively) [26].

The decoration of $\mathrm{Al}$ atoms on the $\mathrm{C}_{2} \mathrm{~N}$ monolayer was then considered. Five different adsorption sites were examined based on the high-symmetry structure shown in Fig. 1(a). The 

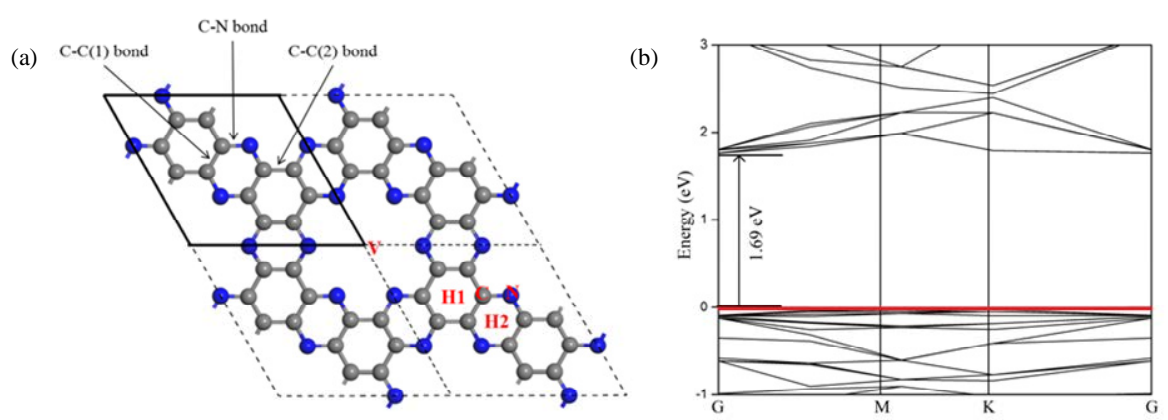

Fig. 1. (a) Top view of the structure of $\mathrm{C}_{2} \mathrm{~N}$ monolayer in a $2 \times 2$ supercell. The grey and blue balls in this and following figures represent the $\mathrm{C}$ and $\mathrm{N}$ atoms, respectively. A $\mathrm{C}_{2} \mathrm{~N}$ unit cell has been marked with a solid black line. Different adsorption sites are considered: vacancy (V), hollow-I (H1), hollow-II (H2), N-top (N) and C-top (C). (b) Band structure of pristine $\mathrm{C}_{2} \mathrm{~N}$ calculated by GGA-PBE.

(a)

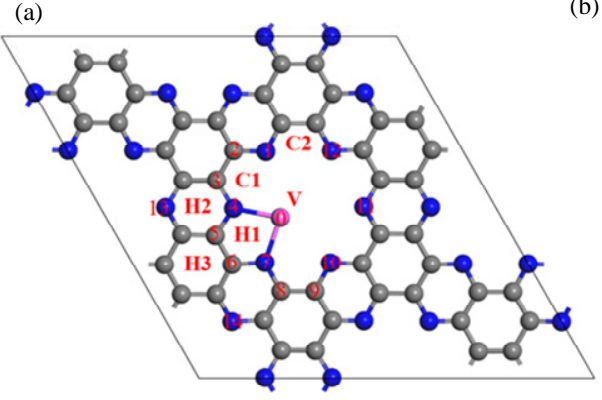

(b)

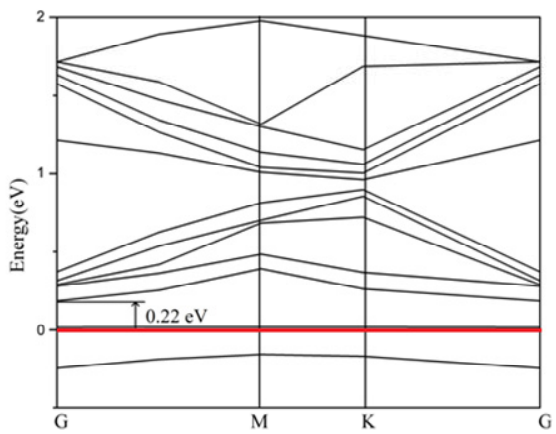

Fig. 2. (a) Top view of Al-decorated $\mathrm{C}_{2} \mathrm{~N}$. The pink ball in this and following figures represents $\mathrm{Al}$ atom. $0-9$ are the atoms besides the decorated $\mathrm{Al}$ atom, which are selected for Mulliken analysis. Different adsorption sites are considered: vacancy (V), hollow- I (H1), hollow-II (H2), hollow-III (H3), corner- I (C1) and corner-II (C2). (b) Band structure of Al-decorated $\mathrm{C}_{2} \mathrm{~N}$ calculated by GGA-PBE.

structure of Al-decorated $\mathrm{C}_{2} \mathrm{~N}$ after full geometry optimization is shown in Fig. 2(a). As can be seen in the figure, the $\mathrm{Al}$ atom prefers to move close to the two nitrogen atoms of the $\mathrm{C}_{2} \mathrm{~N}$ monolayer near the vacancy (V) site, even though its initial position is on the top of a $\mathrm{C}$ or $\mathrm{N}$ atom. A similar conclusion has been reported for of $\mathrm{Li}$ [43] and transition metal ( $\mathrm{Pt}, \mathrm{Co}, \mathrm{Ni}, \mathrm{Cu}$ ) [44] atoms decorated on a $\mathrm{C}_{2} \mathrm{~N}$ layer. The deposition of one $\mathrm{Al}$ atom on the $\mathrm{C}_{2} \mathrm{~N}$ monolayer causes negligible structural changes in the system, and all atoms remain in the same plane without strong deformation. In addition, the decorated $\mathrm{Al}$ atom forms strong chemical bonds with the two $\mathrm{N}$ atoms, with a bond length of $1.97 \AA$. It should be noted that this bond length is longer than both the $\mathrm{C}-\mathrm{C}$ and $\mathrm{C}-\mathrm{N}$ bonds in the $\mathrm{C}_{2} \mathrm{~N}$ monolayer, which reveals that the Al-N bonds are easily broken in a chemical reaction, compared with the pristine $\mathrm{C}_{2} \mathrm{~N}$ system. Previous research has shown that a high concentration of metal atoms leads to their aggregation; in order to verify the structural stability of the Al-decorated $\mathrm{C}_{2} \mathrm{~N}$ system, the binding energy $\left(E_{\mathrm{b}}\right)$ was calculated based on Eq. (1). Table S1 (Supporting Information) shows the calculated binding energy of the decorated $\mathrm{Al}$ atom at different positions on the pristine $\mathrm{C}_{2} \mathrm{~N}$ monolayer. The results show that the $\mathrm{V}$ site has the highest binding energy $\left(E_{\mathrm{b}}=-4.57 \mathrm{eV}\right)$, which exceeds the cohesive energy of bulk $\mathrm{Al}(-3.39 \mathrm{eV} /$ atom) [45]. Thus, the aggregation of $\mathrm{Al}$ atoms in the $\mathrm{C}_{2} \mathrm{~N}$ monolayer can be neglected, confirming the stability of $\mathrm{Al}$-decorated $\mathrm{C}_{2} \mathrm{~N}$. It is worth mentioning that the decorated $\mathrm{Al}$ atom leads to a sharp decrease in the band gap from 1.69 to $0.22 \mathrm{eV}$, as shown in Fig. 2(b), and a similar phenomenon has been also reported by Hashmi et al. [43] for a Li-decorated $\mathrm{C}_{2} \mathrm{~N}$ monolayer. A $3 \times 3 \mathrm{C}_{2} \mathrm{~N}$ supercell was constructed to assess the effect of the loading amount of $\mathrm{Al}$ on the adsorption of both $\mathrm{Al}$ atoms and HCHO molecules. After geometry optimization, the structures of the $3 \times 3$ Al-decorated $\mathrm{C}_{2} \mathrm{~N}$ monolayer with and without adsorbed $\mathrm{HCHO}$ are shown in Fig. S1. Compared with the $2 \times 2 \quad \mathrm{C}_{2} \mathrm{~N}$ monolayer supercell (Al loading amount $\sim 2.9$ $\mathrm{wt} \%$ ), the calculated binding energy of the $\mathrm{Al}$ atom on the $3 \times 3$ $\mathrm{C}_{2} \mathrm{~N}$ monolayer supercell (Al loading amount $\sim 1.3 \mathrm{wt} \%$ ) slightly increases to $-4.87 \mathrm{eV}$. In addition, the adsorption energy of the $\mathrm{HCHO}$ molecule on the Al-decorated $\mathrm{C}_{2} \mathrm{~N}$ also shows a slight change, to $-2.33 \mathrm{eV}$. Therefore, the Al loading amount has a negligible effect on the HCHO adsorption; the maximum $\mathrm{Al}$ loading amount can reach $\sim 10.6 \mathrm{wt} \%$ with one $\mathrm{Al}$ atom at each hollow site of the $\mathrm{C}_{2} \mathrm{~N}$ monolayer. Higher $\mathrm{Al}$ loadings were also considered, with two or three $\mathrm{Al}$ atoms decorated on the same hollow site; however, Al aggregation occurs in these cases, which would negatively affect the adsorption of HCHO molecules and also the possible catalytic degradation performance.

To further understand the strong binding between the decorated $\mathrm{Al}$ atom and the $\mathrm{C}_{2} \mathrm{~N}$ monolayer, we carried out an electron population analysis using the Mulliken method. Because the decorated $\mathrm{Al}$ atom mainly affects the charge distribution in the nearby region, to better describe the electron variation we analyzed the atomic charges of the $\mathrm{Al}$ atom and of 14 atoms (sites 1-14 in Fig. 2) close to it. The results are listed in Table 1. As shown in the table, the electrons show good dispersion on the pristine $\mathrm{C}_{2} \mathrm{~N}$ monolayer, where the $\mathrm{C}$ atoms have charges of 
Table 1

Atomic charges of pristine/Al-decorated $\mathrm{C}_{2} \mathrm{~N}$ monolayer calculated by Mulliken analysis. The unit of the charge is one electron charge $e$.

\begin{tabular}{lcc}
\hline Atom number & Intrinsic $\mathrm{C}_{2} \mathrm{~N}$ & Al-decorated $\mathrm{C}_{2} \mathrm{~N}$ \\
\hline $0(\mathrm{Al})$ & - & 0.843 \\
$1(\mathrm{~N})$ & -0.270 & -0.414 \\
$2(\mathrm{C})$ & 0.135 & 0.152 \\
$3(\mathrm{C})$ & 0.133 & 0.217 \\
$4(\mathrm{~N})$ & -0.267 & -0.630 \\
$5(\mathrm{C})$ & 0.135 & 0.233 \\
$6(\mathrm{C})$ & 0.136 & 0.234 \\
$7(\mathrm{~N})$ & -0.268 & -0.616 \\
$8(\mathrm{C})$ & 0.133 & 0.232 \\
$9(\mathrm{C})$ & 0.133 & 0.160 \\
$10(\mathrm{~N})$ & -0.270 & -0.410 \\
$11(\mathrm{~N})$ & -0.267 & -0.318 \\
$12(\mathrm{~N})$ & -0.268 & -0.314 \\
$13(\mathrm{~N})$ & -0.268 & -0.272 \\
$14(\mathrm{~N})$ & -0.267 & -0.270 \\
\hline
\end{tabular}

0.133-0.135 $e$, whereas the charges of the $\mathrm{N}$ atoms vary between -0.267 and $-0.270 e$. After decorating an $\mathrm{Al}$ atom, the electron distribution shows a marked variation. The $\mathrm{Al}$ atom transfers electrons to the atoms near the vacancy, and carries a $+0.843 e$ charge. In particular, for the $\mathrm{N}$ atoms at sites 4 and 7 , which are directly connected with the $\mathrm{Al}$ atom, the electronic charges change from -0.267 and $-0.268 e$ to -0.630 and -0.616 $e$, respectively. For the $\mathrm{N}$ atoms close to the vacancy at sites 1 , 10,11 , and 12 , the charges are $-0.414,-0.410,-0.318$, and $-0.314 e$, respectively, showing a decreasing ability to attract electrons, which also reflects the distances between the $\mathrm{N}$ atoms and the $\mathrm{Al}$ atom. The $\mathrm{N}$ atoms at sites 13 and 14, close to another vacancy, have electronic charges of -0.270 and -0.272 $e$, respectively, similar to those in the pristine $\mathrm{C}_{2} \mathrm{~N}$ system. This indicates that the decorated $\mathrm{Al}$ atom mainly affects the electron distribution close to the vacancy, and a large number of electrons transfer from the $\mathrm{Al}$ atom, leading to a strong binding between the $\mathrm{Al}$ atom and the $\mathrm{C}_{2} \mathrm{~N}$ layer, as well as achieving a high stability of the decorated structure.

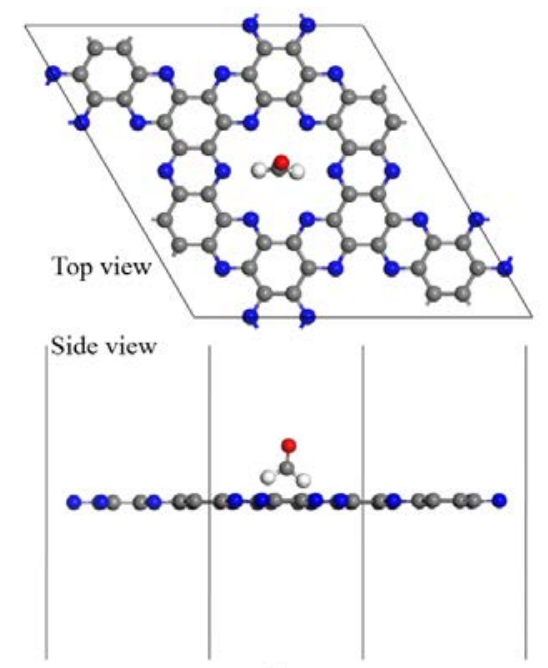

(a)

\section{Table 2}

Results of favorite adsorption configurations of $\mathrm{HCHO}, \mathrm{H}_{2} \mathrm{O}$ and $\mathrm{O}_{2}$ adsorbed on intrinsic/Al-decorated $\mathrm{C}_{2} \mathrm{~N}$ monolayer, respectively. $E_{\text {ad-gas }}$ and $d$ are adsorption energies and adsorption distances between gas molecules and $\mathrm{C}_{2} \mathrm{~N}$ monolayer. $l$ is the bond lengths of decorated $\mathrm{Al}$ atom and the adsorbed gas molecules.

\begin{tabular}{lcccccc}
\hline \multirow{2}{*}{ Type } & \multicolumn{2}{c}{ Intrinsic $\mathrm{C}_{2} \mathrm{~N}$} & & \multicolumn{3}{c}{ Al-decorated $\mathrm{C}_{2} \mathrm{~N}$} \\
\cline { 2 - 3 } \cline { 5 - 7 } & $E_{\text {ad-gas }}(\mathrm{eV})$ & $d(\AA)$ & & $E_{\text {ad-gas }}(\mathrm{eV})$ & $l(\AA)$ & $d(\AA)$ \\
\hline $\mathrm{HCHO}$ & -0.583 & 1.132 & & -2.586 & 1.706 & 1.382 \\
$\mathrm{H}_{2} \mathrm{O}$ & -0.743 & 0.986 & & -3.177 & 1.709 & - \\
$\mathrm{O}_{2}$ & -0.206 & 1.455 & & -2.767 & $1.791 / 1.765$ & 1.789 \\
\hline
\end{tabular}

\subsection{Adsorption behavior of HCHO molecules}

The adsorption of $\mathrm{HCHO}$ molecules on the $\mathrm{C}_{2} \mathrm{~N}$ monolayer was then investigated. Based on the high-symmetry structure, five possible adsorption sites were investigated, denoted as $\mathrm{V}$, C, N, H1, and H2 in Fig. 1(a). After structural relaxation, the most stable adsorption configuration is observed at the $\mathrm{V}$ site, with an adsorption energy $E_{\text {ad-gas }}$ of $-0.583 \mathrm{eV}$, calculated from Eq. (2). The structure of this configuration is shown in Fig. 3(a), and the corresponding structural parameters are listed in Table 2. The figure shows that the HCHO molecule prefers to sit on the vacancy site, with the oxygen atom up and the two hydrogen atoms pointing down; the molecule is located $1.132 \AA$ away from the $\mathrm{C}_{2} \mathrm{~N}$ monolayer and the adsorption energy is -0.583 $\mathrm{eV}$. This short distance is in the range of chemical bonds; however, as can be seen in the figure, the adsorbed HCHO molecule is embedded in the vacancy site of $\mathrm{C}_{2} \mathrm{~N}$, and no chemical bonds are formed. In addition, the adsorption causes negligible structural changes in both the $\mathrm{HCHO}$ molecule and $\mathrm{C}_{2} \mathrm{~N}$ layer, denoting a physisorption behavior. After adsorption, the $\mathrm{C}-\mathrm{O}$ and $\mathrm{C}-\mathrm{H}$ lengths in the HCHO molecule change from 1.212 and $1.117 \AA$ to 1.218 and $1.113 \AA$, respectively. All atoms in the $\mathrm{C}_{2} \mathrm{~N}$ layer maintain a flat arrangement. Table S2 shows the calculated adsorption energies at different adsorption sites, which further confirm that the $\mathrm{HCHO}$ molecule adsorbed on the pris-

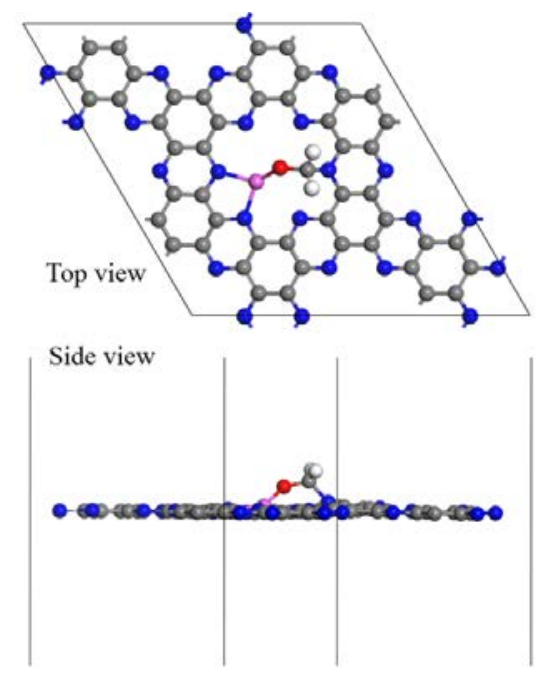

(b)

Fig. 3. The favorite adsorption configurations of a $\mathrm{HCHO}$ molecule adsorbed on (a) intrinsic $\mathrm{C}_{2} \mathrm{~N}$ monolayer and (b) Al-decorated $\mathrm{C}_{2} \mathrm{~N}$ monolayer. The red and white balls in this and following figures represent the $\mathrm{O}$ and $\mathrm{H}$ atoms, respectively. 
tine $\mathrm{C}_{2} \mathrm{~N}$ monolayer undergoes weak physisorption.

Then, we investigated the adsorption of the HCHO molecule on the Al-decorated $\mathrm{C}_{2} \mathrm{~N}$ monolayer, focusing on six possible sites (V, H1, H2, H3, C1, and C2) besides the decorated $\mathrm{Al}$ atom, as shown in Fig. 2(a). The corresponding calculated adsorption energies at these six sites are listed in Table S3. The results show that the preferred adsorption structure involves the HCHO molecule lying on the $\mathrm{V}$ site, with an adsorption energy of $-2.585 \mathrm{eV}$, as shown in Fig. 3(b). The figure shows the presence of two chemical bonds (Al-O and $\mathrm{C}-\mathrm{N}$ ) between the $\mathrm{HCHO}$ molecule and the $\mathrm{C}_{2} \mathrm{~N}$ layer, and the corresponding bond lengths are $1.706 \AA$ ( $\mathrm{Al}-\mathrm{O}$ bond) and $1.524 \AA$ (C-H bond), respectively. As also shown in the figure, the strong adsorption causes the structural distortion of the $\mathrm{C}_{2} \mathrm{~N}$ layer, which exhibits a slight curvature. In particular, the $\mathrm{Al}$ and $\mathrm{N}$ atoms connected with the adsorbed HCHO molecule move toward it, attracting its $\mathrm{C}$ atom toward the $\mathrm{C}_{2} \mathrm{~N}$ layer. The $\mathrm{C}-\mathrm{O}$ and $\mathrm{C}-\mathrm{H}$ bond lengths of the HCHO molecule change from 1.212 and $1.117 \AA$ to 1.383 and $1.100 \AA$, respectively, exhibiting a different adsorption behavior compared with the pristine system. It is worth mentioning that the $\mathrm{Al}$-decorated $\mathrm{C}_{2} \mathrm{~N}$ monolayer shows a better performance for $\mathrm{HCHO}$ adsorption compared with that previously reported for Fe-doped graphene $\left(E_{\text {ad-gas }}=-1.45 \mathrm{eV}\right)$ [46] and Ti-doped graphene ( $E_{\text {ad-gas }}=-2.26 \mathrm{eV}$ ) [47], revealing the potential application for HCHO concentration, use, and treatment.

To further understand the mechanism behind the enhanced adsorption of HCHO molecules on the Al-decorated $\mathrm{C}_{2} \mathrm{~N}$, the PDOS plots of HCHO and pristine/Al-decorated $\mathrm{C}_{2} \mathrm{~N}$ were calculated and displayed in Fig. 4. The overlap between bands in the PDOS is representative of the adsorption strength. For ad-
Table 3

Atomic charges of the absorbed molecules in pristine/Al-derocated $\mathrm{C}_{2} \mathrm{~N}$ monolayer calculated by Mulliken analysis. The unit of charge is $e$.

\begin{tabular}{lcccc}
\hline \multirow{2}{*}{ Type } & Intrinsic $\mathrm{C}_{2} \mathrm{~N}$ & & \multicolumn{2}{c}{ Al-decorated $\mathrm{C}_{2} \mathrm{~N}$} \\
\cline { 2 - 3 } & Adsorbed molecule & & Al atom & Adsorbed molecule \\
\hline $\mathrm{HCHO}$ & 0.115 & & -0.228 & 1.207 \\
$\mathrm{H}_{2} \mathrm{O}$ & 0.065 & & -0.349 & 1.159 \\
$\mathrm{O}_{2}$ & 0.037 & & -0.654 & 1.243 \\
\hline
\end{tabular}

sorption on the Al-decorated $\mathrm{C}_{2} \mathrm{~N}$ monolayer, electron interactions can be clearly observed between the adsorbed molecule, the decorated $\mathrm{Al}$ atom, and the $\mathrm{C}_{2} \mathrm{~N}$ monolayer, as indicated by the blue dashed area in Fig. 4(b). However, in the pristine system, these interactions only involve the adsorbed molecule and the $\mathrm{C}_{2} \mathrm{~N}$ monolayer, as indicated by the red dashed area. In other words, in the Al-decorated system, the electrons of the adsorbed molecule interact not only with the electrons in the $\mathrm{C}_{2} \mathrm{~N}$ monolayer, but also with those of the decorated $\mathrm{Al}$ atom. Thus, the $\mathrm{Al}$ atom acts as a bridge connecting the $\mathrm{HCHO}$ molecule and the $\mathrm{C}_{2} \mathrm{~N}$ monolayer, which strengthens the interaction between electrons and enhances the adsorption. In addition, the PDOS curve of the Al-decorated system is shifted to the left (i.e., toward lower energies) compared to that of the pristine system, indicating a more stable adsorption.

Furthermore, the Mulliken population analysis was performed to obtain the specific charges of the HCHO molecule and $\mathrm{Al}$ atoms. The results are displayed in Table 3. A considerably stronger electron transfer is observed in the Al-decorated system, indicating a stronger interaction between the HCHO molecule and the $\mathrm{C}_{2} \mathrm{~N}$ layer. To analyze the distribution of electrons in more detail, we calculated the electron density distribution
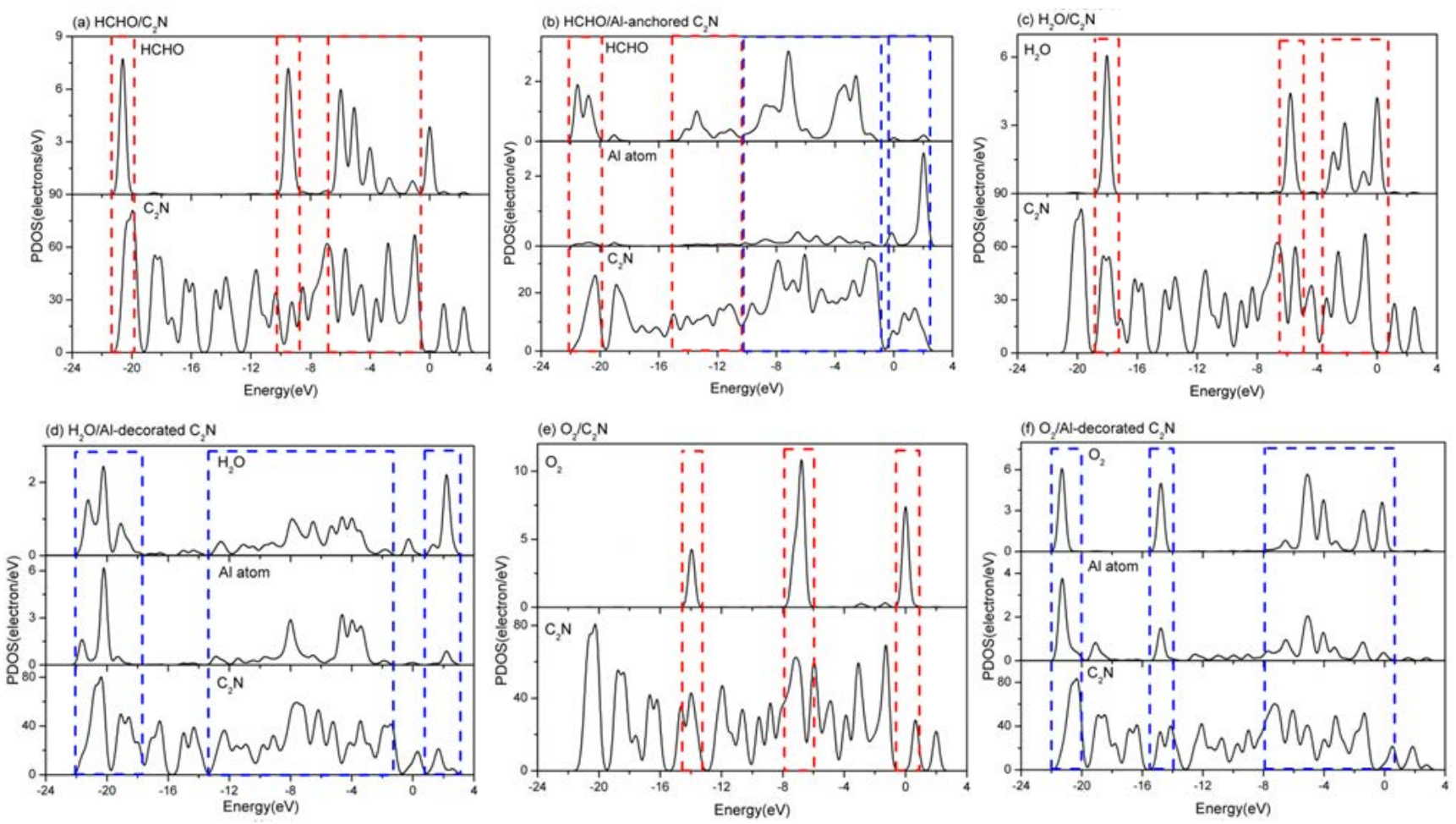

Fig. 4. The PDOS of adsorbed gas molecules, decorated $\mathrm{Al}$ atom and $\mathrm{C}_{2} \mathrm{~N}$ monolayer. The red dash indicates the overlap areas of adsorbed molecules and $\mathrm{C}_{2} \mathrm{~N}$, while the blue dash indicates the overlap areas of the adsorbed molecules, the decorated $\mathrm{Al}$ atom and the $\mathrm{C}_{2} \mathrm{~N}$. 


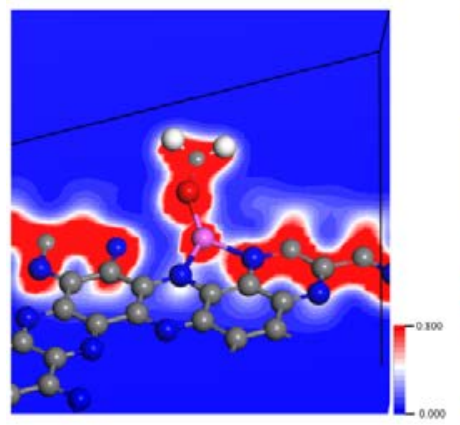

(a)

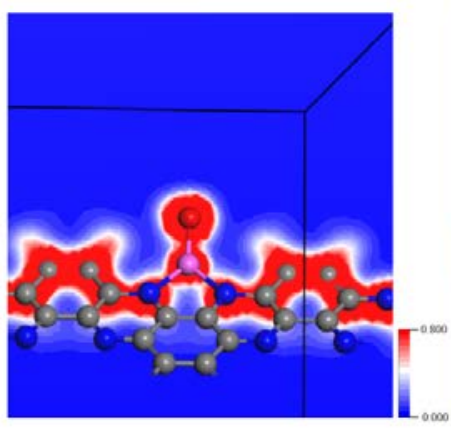

(b)

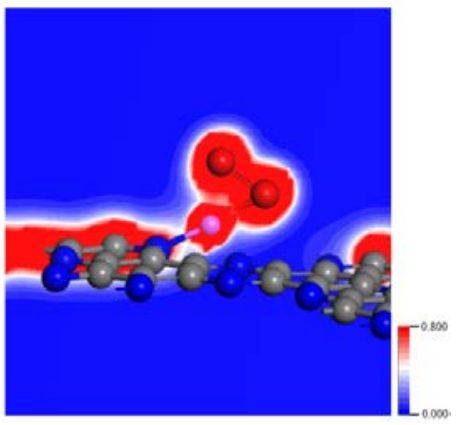

(c)

Fig. 5. Electronic density distribution of (a) $\mathrm{HCHO}$, (b) $\mathrm{H}_{2} \mathrm{O}$, and (c) $\mathrm{O}_{2}$ adsorbed on the Al-decorated $\mathrm{C}_{2} \mathrm{~N}$.

of the HCHO molecule adsorbed on Al-decorated $\mathrm{C}_{2} \mathrm{~N}$, shown in Fig. 5(a). The electron cloud extends over the decorated $\mathrm{Al}$ atom, the $\mathrm{C}_{2} \mathrm{~N}$ monolayer, and the adsorbed HCHO molecule, which is consistent with the band overlap in the PDOS shown in Fig. 4(a), and induces the strong adsorption of gas molecules. In addition, a relatively higher density of the electron cloud can be observed among the decorated $\mathrm{Al}$ atom, the $\mathrm{C}_{2} \mathrm{~N}$ monolayer, and the adsorbed HCHO molecule. These results further confirm that the $\mathrm{Al}$ atom acts as a bridge connecting the $\mathrm{HCHO}$ molecule and the $\mathrm{C}_{2} \mathrm{~N}$ layer. This indicates that the decorated $\mathrm{Al}$ atom alters the electron distribution and lead to the enhanced adsorption of HCHO molecules, which is in good agreement with the other results discussed above.

\subsection{Adsorption of $\mathrm{H}_{2} \mathrm{O}$ and $\mathrm{O}_{2}$ molecules for possible catalytic degradation of $\mathrm{HCHO}$}

As discussed above, the HCHO molecule can be strongly adsorbed on the Al-decorated $\mathrm{C}_{2} \mathrm{~N}$, which provides an excellent precondition for the subsequent treatment. Different techniques for the degradation of HCHO molecules are available, such as electro-Fenton [48], electro-oxidation [49,50], and photocatalysis processes [51-53]. Among these degradation methods, the generation of the hydroxyl $(\cdot \mathrm{OH})$ and superoxide $\left(\mathrm{O}_{2}{ }^{-}\right)$radicals usually plays a crucial role in the oxidation pro- cesses [54-61]. As these two radicals are generally derived from $\mathrm{H}_{2} \mathrm{O}$ and $\mathrm{O}_{2}$, it is also necessary to investigate the adsorption behavior of these two molecules. Therefore, we also investigated the adsorption of $\mathrm{H}_{2} \mathrm{O}$ and $\mathrm{O}_{2}$ molecules on pristine and Al-decorated $\mathrm{C}_{2} \mathrm{~N}$ monolayer. Similar to the adsorption of volatile organic compounds (VOCs) discussed above, we considered five possible adsorption sites $(\mathrm{V}, \mathrm{C}, \mathrm{N}, \mathrm{H} 1$, and $\mathrm{H} 2$ as shown in Fig. 1(a)) on the pristine $\mathrm{C}_{2} \mathrm{~N}$ monolayer and six possible sites (V, H1, H2, H3, C1, and C2 as shown in Fig. 2(a)), besides the decorated $\mathrm{Al}$ atom, on the $\mathrm{Al}$-decorated $\mathrm{C}_{2} \mathrm{~N}$ monolayer. The calculated adsorption energies are listed in Table S2 and Table S3, respectively.

The most stable configurations for a water molecule adsorbed on the pristine and Al-decorated $\mathrm{C}_{2} \mathrm{~N}$ monolayer are shown in Figs. 6(a) and 6(b), respectively, and the corresponding structural parameters are listed in Table 2 . In the pristine system, Fig. 6(a) shows that the $\mathrm{H}_{2} \mathrm{O}$ molecule prefers to lie above the $\mathrm{V}$ site of the $\mathrm{C}_{2} \mathrm{~N}$ monolayer, with the oxygen atom up and the two hydrogen atoms pointing downward. The calculated adsorption energy is $-0.743 \mathrm{eV}$. The distance between the $\mathrm{H}_{2} \mathrm{O}$ molecule and the $\mathrm{C}_{2} \mathrm{~N}$ monolayer is $0.986 \AA$, and no chemical bonds are formed. The two $\mathrm{O}-\mathrm{H}$ bond lengths of the water molecule increase from $0.968 \AA$ in the isolated $\mathrm{H}_{2} \mathrm{O}$ molecule to $0.978 \AA$ in the adsorbed state. After $\mathrm{Al}$ atom decoration on the $\mathrm{C}_{2} \mathrm{~N}$ layer, the most stable adsorption configuration is shown in

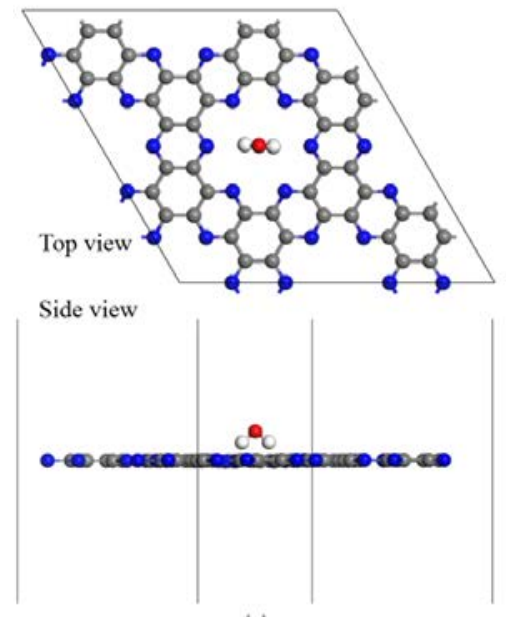

(a)

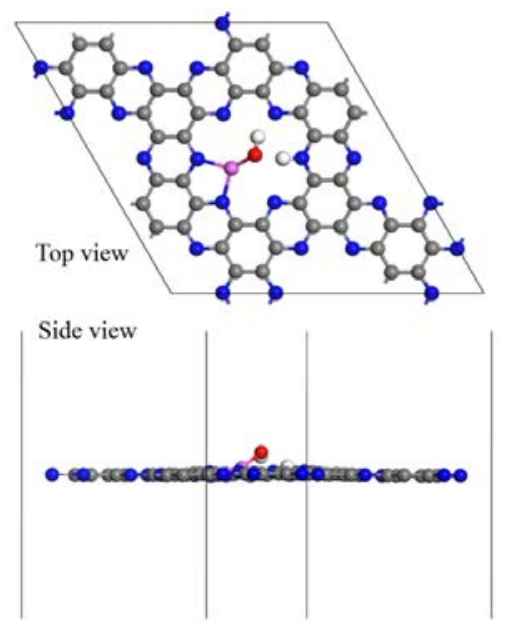

(b)

Fig. 6. The favorite adsorption configurations of a $\mathrm{H}_{2} \mathrm{O}$ molecule adsorbed on (a) intrinsic $\mathrm{C}_{2} \mathrm{~N}$ and (b) Al-decorated $\mathrm{C}_{2} \mathrm{~N}$. 


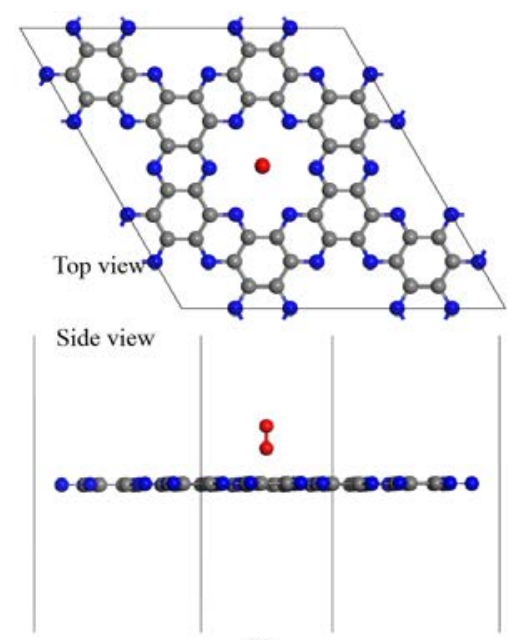

(a)

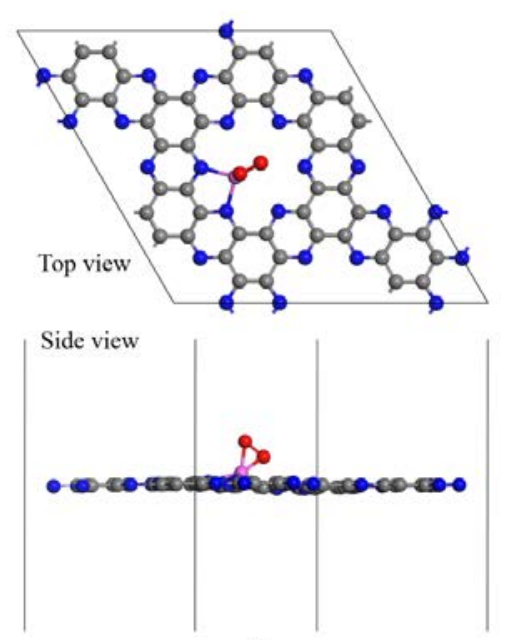

(b)

Fig. 7. The favorite adsorption configurations of an $\mathrm{O}_{2}$ molecule adsorbed on (a) intrinsic $\mathrm{C}_{2} \mathrm{~N}$ and (b) Al-decorated $\mathrm{C}_{2} \mathrm{~N}$.

Fig. 6(b). The obtained adsorption energy is $-3.177 \mathrm{eV}$, which is around four times higher than that measured in the pristine system. This strong adsorption causes slight structural changes in the Al-decorated $\mathrm{C}_{2} \mathrm{~N}$ sheet as well as induces the dissociation of the $\mathrm{H}_{2} \mathrm{O}$ molecule into an $-\mathrm{OH}$ group and a $\mathrm{H}$ atom, which is attached to the decorated $\mathrm{Al}$ atom with $\mathrm{Al}-\mathrm{O}$ and $\mathrm{N}-\mathrm{H}$ bond lengths of 1.709 and $1.049 \AA$, respectively. This indicates a very strong interaction between the $\mathrm{H}_{2} \mathrm{O}$ molecule and the Al-decorated $\mathrm{C}_{2} \mathrm{~N}$.

In the case of $\mathrm{O}_{2}$ adsorption on pristine and Al-decorated $\mathrm{C}_{2} \mathrm{~N}$ monolayer, we found that the $\mathrm{O}_{2}$ molecule also prefers to adsorb on the $\mathrm{V}$ site; the most stable structure is shown in Fig. 7 (a). As shown in the figure, in the pristine $\mathrm{C}_{2} \mathrm{~N}$ system the $\mathrm{O}_{2}$ molecule lies perpendicular to the center of the vacancy site, with an adsorption energy of $-0.206 \mathrm{eV}$. This relatively weak adsorption has negligible impact of the $\mathrm{C}_{2} \mathrm{~N}$ monolayer. The O-O bond length of the $\mathrm{O}_{2}$ molecule increases from $1.225 \AA$ in an isolated $\mathrm{O}_{2}$ molecule to $1.288 \AA$ after adsorption. In addition, the $\mathrm{O}_{2}$ molecule is nearly $1.5 \AA$ away from the $\mathrm{C}_{2} \mathrm{~N}$ layer, which is large than the distance observed for the HCHO molecule (around $0.9 \AA$ ), and the corresponding adsorption energy is also lower than that of the HCHO molecule $(-0.743 \mathrm{eV})$. However, in the Al-decorated system, regardless of its initial position, the $\mathrm{O}_{2}$ molecule prefers to move to the $\mathrm{V}$ site after geometry optimization; the final structure is shown in Fig. 7(b). The $\mathrm{O}_{2}$ molecule prefers to lie near the vacancy site $\left(E_{\text {ad-gas }}=-2.767\right.$ $\mathrm{eV}$ ); as the $\mathrm{O}=\mathrm{O}$ bond breaks, both $\mathrm{O}$ atoms form chemical bonds with the $\mathrm{Al}$ atom, as shown in the side view of Fig. 5(b). The two Al-O bond lengths are 1.791 and $1.765 \AA$, while the O-O bond length increases to $1.516 \AA$, which is much longer than that of an isolated $\mathrm{O}_{2}$ molecule $(1.225 \AA)$ and of the $\mathrm{O}_{2}$ molecule adsorbed on the pristine $\mathrm{C}_{2} \mathrm{~N}$ monolayer (1.288 $\AA$ ). Furthermore, the Al-decorated $\mathrm{C}_{2} \mathrm{~N}$ monolayer exhibits slight distortion with the $\mathrm{Al}$ atom shifted toward the adsorbed $\mathrm{O}_{2}$ molecule.

Therefore, the decoration of $\mathrm{Al}$ atoms on $\mathrm{C}_{2} \mathrm{~N}$ can significantly enhance the adsorption of $\mathrm{H}_{2} \mathrm{O}$ and $\mathrm{O}_{2}$ molecules as well. In particular, the hydroxyl group can be formed directly upon
$\mathrm{H}_{2} \mathrm{O}$ adsorption, which greatly benefits the generation of hydroxyl radicals. On the other hand, the chemisorbed $\mathrm{O}_{2}$ molecules also have a much higher ability to attract additional electrons, with a high potential to be activated into superoxide radicals. Therefore, the $\mathrm{Al}$-decorated $\mathrm{C}_{2} \mathrm{~N}$ could be a promising novel material for concentrating VOCs, as well as for their degradation through radical routes.

Similar to the case of $\mathrm{HCHO}$ molecules on the Al-decorated $\mathrm{C}_{2} \mathrm{~N}$ monolayer, the PDOS of the $\mathrm{H}_{2} \mathrm{O}$ and $\mathrm{O}_{2}$ molecules on the pristine/Al-decorated $\mathrm{C}_{2} \mathrm{~N}$ systems were also calculated and are displayed in Fig. 4. Based on the band overlap, the electron interactions between the $\mathrm{H}_{2} \mathrm{O}$ or $\mathrm{O}_{2}$ molecule, the decorated $\mathrm{Al}$ atom, and the $\mathrm{C}_{2} \mathrm{~N}$ monolayer (indicated as blue dashed areas in Figs. 6(d) and 6(f)) are considerably stronger than the interaction in the pristine system, indicated by the red dashed band overlap in Figs. 6(c) and 6(e). Therefore, a similar adsorption enhancement mechanism can be achieved, with the $\mathrm{Al}$ atom acting as a bridge to connect the $\mathrm{H}_{2} \mathrm{O}$ or $\mathrm{O}_{2}$ molecule and the $\mathrm{C}_{2} \mathrm{~N}$ monolayer, strengthening the interaction between electrons and enhancing the adsorption. In addition, Mulliken atomic charges were calculated for the $\mathrm{H}_{2} \mathrm{O}$ and $\mathrm{O}_{2}$ molecules on the pristine and Al-decorated $\mathrm{C}_{2} \mathrm{~N}$ systems, and the results are listed in Table 3, while the corresponding electron density distribution is shown in Figs. 5(b) and 5(c). Similar to HCHO, the electron transfer is considerably stronger in the Al-decorated system, and the electron cloud extends over the adsorbed $\mathrm{HCHO}$, the decorated $\mathrm{Al}$ atom, and the $\mathrm{C}_{2} \mathrm{~N}$ monolayer, inducing the strong adsorption of the gas molecules.

\section{Conclusions}

The adsorption behavior of the HCHO molecule and the potential catalytic degradation ability of pristine and Al-decorated $\mathrm{C}_{2} \mathrm{~N}$ monolayer were investigated using first-principles calculations. Because the adsorption of the HCHO molecule on the pristine $\mathrm{C}_{2} \mathrm{~N}$ monolayer is relatively weak $\left(E_{\text {ad-gas }}=-0.583 \mathrm{eV}\right)$ and not suitable for its concentration and subsequent treatment, $\mathrm{Al}$ atoms were decorated on the $\mathrm{C}_{2} \mathrm{~N}$ layer, resulting in a 
high $\mathrm{HCHO}$ adsorption energy of $-2.586 \mathrm{eV}$. Moreover, the $\mathrm{H}_{2} \mathrm{O}$ and $\mathrm{O}_{2}$ molecules were strongly adsorbed on the Al-decorated $\mathrm{C}_{2} \mathrm{~N}$ monolayer, providing a favorable precondition for the possible generation of hydroxyl and superoxide radicals. In particular, the $\mathrm{H}_{2} \mathrm{O}$ molecule dissociated spontaneously and generated a hydroxyl group connected with the $\mathrm{Al}$ atom on the $\mathrm{C}_{2} \mathrm{~N}$ surface, revealing its promising potential for the generation of hydroxyl radicals. Furthermore, we investigated the adsorption enhancement mechanism for $\mathrm{HCHO}, \mathrm{H}_{2} \mathrm{O}$, and $\mathrm{O}_{2}$ molecules. The results showed that the decorated $\mathrm{Al}$ atom can alter the electron distribution and thus the chemical and physical properties in its vicinity, acting as a bridge between the $\mathrm{HCHO}$ molecule and the $\mathrm{C}_{2} \mathrm{~N}$ layer, and strengthening the adsorption. Hence, the Al-decorated $\mathrm{C}_{2} \mathrm{~N}$ monolayer proved to be an excellent material for the adsorption and possible catalytic degradation of $\mathrm{HCHO}$ molecules.

\section{References}

[1] N. E. Klepeis, W. C. Nelson, W. R. Ott, J. P. Robinson, A. M. Tsang, P. Switzer, J. V. Behar, S. C. Hern, W. H. Engelmann, J. Expo. Anal. Environ. Epidemiol., 2001, 11, 231-252.

[2] T. Salthammer, S. Mentese, R. Marutzky, Chem. Rev., 2010, 110, 2536-2572.

[3] R. K. Nath, M. F. M. Zain, M. Jamil, Renew. Sustain. Energy Rev., 2016, 62, 1184-1194.

[4] U. Schlink, S. Röder, T. Kohajda, D. K. Wissenbach, U. Franck, I. Lehmann, Build. Environ., 2016, 105, 198-209.

[5] Y. Su, Z. Ao, Y. Ji, G. Li, T. An, Appl. Surf. Sci., 2018, 450, 484-491.

[6] K. A. Mundt, A. E. Gallagher, L. D. Dell, E. A. Natelson, P. Boffetta, P. R. Gentry, Crit. Rev. Toxicol., 2017, 47, 598-608.

[7] M. Hauptmann, J. H. Lubin, P. A. Stewart, R. B. Hayes, A. Blair, Am. J. Epidemiol., 2004, 159, 1117-1130.

[8] X. Tang, Y. Bai, A. Duong, M. T. Smith, L. Li, L. Zhang, Environ. Int., 2009, 35, 1210-1224.

[9] X. S. Zhao, Q. Ma, G. Q. Lu, Energy Fuels, 1998, 12, 1051-1054.

[10] J. Li, P. Zhang, J. Wang, M. Wang, J. Phys. Chem. C, 2016, 120, 24121-24129.

[11] J. H. Shen, Y. S. Wang, J. P. Lin, S. H. Wu, J. J. Horng, J. Air Waste Manage. Assoc., 2014, 64, 13-18.
[12] X. Zhu, J. Yu, C. Jiang, B. Cheng, Phys. Chem. Chem. Phys., 2017, 19, 6957-6963.

[13] L. Nie, J. Yu, M. Jaroniec, F. F. Tao, Catal. Sci. Technol., 2016, 6, 3649-3669.

[14] R. R. Bansode, J. N. Losso, W. E. Marshall, R. M. Rao, R. J. Portier, Bioresource Technol., 2003, 90, 175-184.

[15] V. Boonamnuayvitaya, S. Sae-ung, W. Tanthapanichakoon, Sep. Purif. Technol., 2005, 42, 159-168.

[16] Y. Matsuo, Y. Nishino, T. Fukutsuka, Y. Sugie, Carbon, 2008, 46, 1162-1163.

[17] T. Liu, F. Li, X. Li, J. Hazard. Mater., 2008, 152, 347-355.

[18] A. A. Ismail, Appl. Catal. B, 2012, 117-118, 67-72.

[19] Z. Xu, J. Yu, W. Xiao, Chem. Eur. J., 2013, 19, 9592-9598.

[20] R. J. Wu, Y. S. Liu, H. F. Lai, J. H. Wang, M. Chavali, J. Nanosci. Nanotechnol., 2014, 14, 6792-6799.

[21] I. Jansson, S. Suárez, F. J. Garcia-Garcia, B. Sánchez, Appl. Catal. B, 2015, 178, 100-107.

[22] B. Bai, Q. Qiao, J. Li, J. Hao, Chin. J. Catal., 2016, 37, 102-122.

[23] R. Liu, J. Wang, J. Zhang, S. Xie, X. Wang, Z. Ji, Microporous Mesoporous Mater., 2017, 248, 234-245.

[24] J. Melcher, S. Feroz, D. Bahnemann, J. Mater. Sci., 2017, 52, 6341-6348.

[25] J. Shang, W. W. Xu, C. X. Ye, C. George, T. Zhu, Sci. Rep., 2017, 7, 1161/1-1161/9.

[26] J. Mahmood, E. K. Lee, M. Jung, D. Shin, I. Y. Jeon, S. M. Jung, H. J. Choi, J. M. Seo, S. Y. Bae, S. D. Sohn, N. Park, J. H. Oh, H. J. Shin, J. B. Baek, Nat. Commun., 2015, 6, 6486.

[27] L. Zhu, Q. Xue, X. Li, T. Wu, Y. Jin, W. Xing, J. Mater. Chem. A, 2015, 3, 21351-21356.

[28] Y. Liu, Z. Meng, X. Guo, G. Xu, D. Rao, Y. Wang, K. Deng, R. Lu, Phys. Chem. Chem. Phys., 2017, 19, 28323-28329.

[29] G. Q. Qin, A. J. Du, Q. Sun, Energy Technol., 2018, 6, 205-212.

[30] K. Bhattacharyya, S. M. Pratik, A. Datta, J. Phys. Chem. C, 2018, 122, 2248-2258.

[31] Z. M. Ao, J. Yang, S. Li, Q. Jiang, Chem. Phys. Lett., 2008, 461, 276-279.

[32] Z. M. Ao, Q. Jiang, R. Q. Zhang, T. T. Tan, S. Li, J. Appl. Phys., 2009, 105, 074307/1-074307/6.

[33] Z. M. Ao, F. M. Peeters, Phys. Rev. B, 2010, 81, 205406/1-205406/7.

[34] H. Luo, Y. Cao, J. Zhou, J. Feng, J. Cao, H. Guo, Chem. Phys. Lett.,

\section{Graphical Abstract}

Chin. J. Catal., 2019, 40: 664-672 doi: 10.1016/S1872-2067(18)63201-2

\section{Density functional theory investigation of the enhanced adsorption mechanism and potential catalytic activity for formaldehyde degradation on Al-decorated $\mathrm{C}_{2} \mathrm{~N}$ monolayer}

Yuetan Su, Wenlang Li, Guiying Li, Zhimin Ao *, Taicheng An Guangdong University of Technology

Al-decorated $\mathrm{C}_{2} \mathrm{~N}$ can enhance the $\mathrm{HCHO}$ adsorption capacity and the subsequent generation of hydroxyl $(\cdot \mathrm{OH})$ and superoxide $\left(\mathrm{O}_{2}{ }^{-}\right)$radicals; therefore, it represents a promising material for the adsorption and possible catalytic degradation of $\mathrm{HCHO}$.

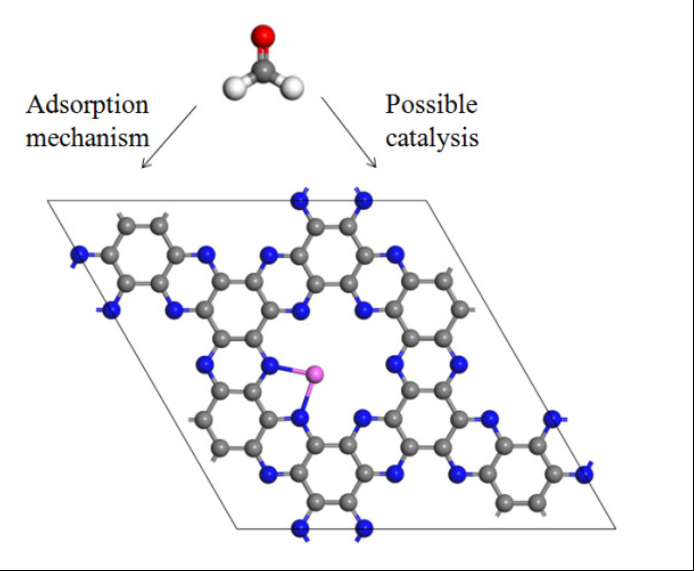


2016, 643, 27-33.

[35] S. Noorizadeh, E. Shakerzadeh, Comput. Mater. Sci., 2012, 56, 122-130.

[36] S. Q. Ma, Adv. Mater. Res., 2011, 197-198, 701-704.

[37] P. Shao, X. Y. Kuang, L. P. Ding, J. Yang, M. M. Zhong, Appl. Surf. Sci., 2013, 285, 350-356.

[38] B. Delley, J. Chem. Phys., 1990, 92, 508-517.

[39] B. Delley, J. Chem. Phys., 2000, 113, 7756-7764.

[40] J. P. Perdew, K. Burke, M. Ernzerhof, Phys. Rev. Lett., 1998, 80, 891.

[41] Y. Yang, M. Guo, G. Zhang, W. Li, Carbon, 2017, 117, 120-125.

[42] S. Guan, Y. Cheng, C. Liu, J. Han, Y. Lu, S. A. Yang, Y. Yao, Appl. Phys. Lett., 2015, 107, 231904/1-231904/5.

[43] A. Hashmi, M. U. Farooq, I. Khan, J. Son, J. Hong, J. Mater. Chem. A, 2017, 5, 2821-2828.

[44] X. Li, W. Zhong, P. Cui, J. Li, J. Jiang, J. Phys. Chem. Lett., 2016, 7, 1750-1755.

[45] R. Gaudoin, W. M. C. Foulkes, G. Rajagopal, J. Phys. Condens. Mat., 2002, 14, 8787-8793.

[46] D. Cortés-Arriagada, N. Villegas-Escobar, S. Miranda-Rojas, A. Toro-Labbé, Phys. Chem. Chem. Phys., 2017, 19, 4179-4189.

[47] H. P. Zhang, X. G. Luo, X. Y. Lin, X. Lu, Y. Leng, H. T. Song, Appl. Surf. Sci., 2013, 283, 559-565.

[48] G. Moussavi, A. Bagheri, A. Khavanin, J. Hazard. Mater., 2012, 237-238, 147-152.
[49] S. N. Azizi, S. Ghasemi, M. Derakhshani-mansoorkuhi, Int. J. Hydrogen Energy, 2016, 41, 21181-21192.

[50] Y. Huang, K. Ye, H. Li, W. Fan, F. Zhao, Y. Zhang, H. Ji, Nano Res., 2016, 9, 3881-3892.

[51] G. Wu, C. Zhao, C. Guo, J. Chen, Y. Zhang, Y. Li, Appl. Surf. Sci., 2018, 428, 954-963.

[52] Z. Shayegan, C. S. Lee, F. Haghighat, Chem. Eng. J., 2018, 334, 2408-2439.

[53] G. Zhang, A. Song, Y. Duan, S. Zheng, Microporous Mesoporous Mater., 2018, 255, 61-68.

[54] G. Mamba, A. K. Mishra, Appl. Catal. B, 2016, 198, 347-377.

[55] B. Jing, Z. Ao, Z. Teng, C. Wang, J. Yi, T. An, Sustain. Mater. Technol., 2018, 16, 12-22.

[56] J. Li, P. Yan, K. Li, W. Cen, X. Yu, S. Yuan, Y. Chu, Z. Wang, Chin. J. Catal., 2018, 39, 1695-1703.

[57] J. Li, X. Dong, Y. Sun, G. Jiang, Y. Chu, S. C. Lee, F. Dong, Appl. Catal. $B, \mathbf{2 0 1 8}, 239,187-195$.

[58] T. Liao, Z. Sun, J. H. Kim, S. X. Dou, Nano Energy, 2017, 32, 209-215.

[59] T. Liao, L. Kou, A. Du, Y. Gu, Z. Sun, J. Am. Chem. Soc., 2018, 140, 9159-9166.

[60] T. Liao, Z. Sun, C. Sun, S. X. Dou, D. J. Searles, Sci. Rep., 2014, 4, 6256/1-6256/7.

[61] T. Liao, L. Kou, A. Du, L. Chen, C. Cao, Z. Sun, Adv. Theory Simul., 2018, 1, 1700033.

\title{
$\mathrm{Al}$ 修饰 $\mathrm{C}_{2} \mathrm{~N}$ 对甲醛降解的吸附增强机理及潜在催化活性的密度泛函理论研究
}

\author{
苏岳檀, 李文浪, 李桂英, 敖志敏 ${ }^{*}$, 安太成 \\ 广东工业大学环境健康与污染控制研究院, 环境科学与工程学院, 广州市环境催化及污染控制重点实验室, 广东广州510006
}

摘要: 羰基化合物, 特别是甲醛, 是室内最常见的对人体有害的空气污染物之一. 如何对甲醛进行有效的控制已成为当前 研究热点. 在本工作中, 我们使用密度泛函理论化学计算方法研究了甲醛分子在 $\mathrm{C}_{2} \mathrm{~N}$ 和 $\mathrm{Al}$ 修饰 $\mathrm{C}_{2} \mathrm{~N}$ 上的吸附性能. 结果表 明, 纯 $\mathrm{C}_{2} \mathrm{~N}$ 对甲醛分子的吸附能力较弱, 吸附能仅为 $-0.583 \mathrm{eV}, \mathrm{C}_{2} \mathrm{~N}$ 经 $\mathrm{Al}$ 原子修饰改性后, 吸附能为 $-2.585 \mathrm{eV}$, 超过了改性 前的 4 倍, 有效增强了体系对甲醛分子的吸附能力. 为了研究甲醛分子在 $\mathrm{Al}$ 修饰 $\mathrm{C}_{2} \mathrm{~N}$ 上的吸附增强机理, 我们对局部态密度 (PDOS)、Mulliken电荷分布及电子密度分布进行了计算. 结果表明, Al 原子修饰改变了附近的电子分布, 从而改变了修饰 $\mathrm{Al}$ 原子的化学和物理行为, 使其起到了连接甲醛分子和 $\mathrm{C}_{2} \mathrm{~N}$ 层的桥梁作用, 从而加强了吸附能力.

此外, 为了研究产生对甲醛活化有效的羟基自由基 $(\cdot \mathrm{OH})$ 和超氧 $\left(\mathrm{O}_{2}{ }^{-}\right)$自由基的可能, 我们还计算了 $\mathrm{C}_{2} \mathrm{~N}$ 结构对 $\mathrm{H}_{2} \mathrm{O}$ 分子 和 $\mathrm{O}_{2}$ 分子的吸附. 结果表明, $\mathrm{Al}$ 修饰的 $\mathrm{C}_{2} \mathrm{~N}_{\text {对 }} \mathrm{H}_{2} \mathrm{O}$ 分子和 $\mathrm{O}_{2}$ 分子同样有很强的吸附能力. 对于 $\mathrm{H}_{2} \mathrm{O}$ 分子, 在纯 $\mathrm{C}_{2} \mathrm{~N}$ 结构中的 吸附能为 $-0.743 \mathrm{eV}$, 在 $\mathrm{Al}$ 原子修饰后的结构中, 其吸附能高达 $-3.177 \mathrm{eV}$, 并且此时 $\mathrm{H}_{2} \mathrm{O}$ 分子能够自发解离成一个羟基和一 个 $\mathrm{H}$ 原子, 其中羟基与修饰的 $\mathrm{Al}$ 原子相连, 这为羟基自由基的生成提供了良好的条件. 而对于 $\mathrm{O}_{2}$ 分子, 在纯 $\mathrm{C}_{2} \mathrm{~N}$ 结构中的吸 附能仅为 $-0.206 \mathrm{eV}$, 在 $\mathrm{Al}$ 原子修饰后其吸附能高达 $-2.767 \mathrm{eV}$, 约为修饰前的 13 倍, 这使得化学吸附的 $\mathrm{O}_{2}$ 分子也具有更高的 获得额外电子和高电位被激活为超氧自由基的潜能, 这也为超氧自由基的生成提供了良好基础. 上述研究表明, $\mathrm{Al}$ 修饰 $\mathrm{C}_{2} \mathrm{~N}$ 是一种有前途的材料, 可用于甲醛分子的吸附及催化降解.

关键词: $\mathrm{C}_{2} \mathrm{~N}$; 密度泛函理论; 二维材料; 甲酫; 吸附; 催化降解

收稿日期: 2018-10-21. 接受日期: 2018-11-17. 出版日期: 2019-05-05.

*通讯联系人. 电子信箱: zhimin.ao@gdut.edu.cn

基金来源：国家自然科学基金目(21607029，21777033，41373102); 广东省科技计划(2017B020216003); 广州市科技计划 (201707010359); 广东省教育厅创新团队项目(2017KCXTD012); 国家“千人计划”青年项目.

本文的电子版全文由Elsevier出版社在ScienceDirect上出版(http://www.sciencedirect.com/science/journal/18722067). 